American Journal of Environmental Sciences 8 (3): 311-321, 2012

ISSN 1553-345X

(C) 2012 Science Publications

\title{
Measurement of Ground Level Ozone at Different Locations
}

\author{
Yasmen A. Mustafa and Sinan J. Mohammed \\ Department of Environmental Engineering, College of Engineering, \\ University of Baghdad, P.O. Box 47121, Jadria, Baghdad, Iraq
}

\begin{abstract}
Problem statement: Ground level ozone is the most important index substance of photochemical smog. Photochemical smog is now observed in many urban and industrial centers around the world and it has become a common phenomenon in many large cities. Ozone is a most harmful pollutant for humans, in addition it plays an important role in damaging vegetation and materials. Therefore it becomes important to measure the ground level ozone at different locations especially in the center of cities. Approach: The ground level ozone concentration at different locations in Baghdad city was identified. Five different sites have been chosen to identify the ground level ozone concentration. Two sites were chosen as areas contained point source (power plant station) in addition to high traffic load and the other three sites were chosen as areas containing heavy traffic only (line source). The measurement focuses on spring and fall because these periods display favorable meteorology to ozone formation. Results: During the research period the maximum values (peaks) for ground level ozone concentration were observed in the fall: at Al-Za'afarania area 101ppb as an average, at Al-Dora $87 \mathrm{ppb}$ as an average (which represent the point sources) and at line source areas $48 \mathrm{ppb}$ as an average. In spring, the peaks of ozone concentration observed to be at the same height, about $50 \mathrm{ppb}$ for all sites. Conclusion: The results show that the effect of power plant stations in forming ozone is larger than traffic load. The comparison between the ground level ozone concentrations that measured during the research period in spring and fall and the Ambient Air Quality Standards (AAQS) shows that: (1) No exceeded levels were observed in spring for all sites. (2) In the fall, the AAQS for ozone was exceeded in Al-Za' afarania area at 12: PM, 1: PM, 2: PM and 3: PM and in Al-Dora at 2: PM.
\end{abstract}

Key words: Gas Sensitive Semiconductor (GSS), Geographical Positioning System (GPS), United States Environmental Protection Agency (USEPA), Local Standard Time (LST), Ambient Air Quality Standards (AAQS)

\section{INTRODUCTION}

It has been reported that the tropospheric Ozone $\left(\mathrm{O}_{3}\right)$ is the principal index substance of photochemical smog. It has been recognized as one of the principal pollutants that degrades air quality (Eijkeren et al., 2002). Ozone is unique among pollutants because it is not emitted directly into the air. Ozone is produced when the primary pollutants, nitrogen oxides $\mathrm{NO}_{\mathrm{x}}$ and the volatile organic compounds VOCs (often called Non-Methane Hydrocarbons, (NMHC), which are referred as ozone precursors, interact under the action of sunlight. Meteorological parameters (temperature, wind speed and direction, solar radiation, humidity and boundary layer depth) highly influence the formation and dispersion of ozone. Radiation, temperature and humidity drive the chemical reactions producing ozone, while boundary layer characteristics and the absence of wind are the factors which respectively lead to the build-up of precursors and limit their dispersion. Ozone formation/destruction indicates that the whole mechanism is particularly controlled by meteorological parameters. The concentration is varied widely from region to region, with the time of the year and the time of the day (Langyel et al., 2004; Jose et al., 2005; Al-Alawi et al., 2008).

Both $\mathrm{NO}_{\mathrm{x}}$ and VOCs are emitted from a large pool of sources. These sources are typically classified into four categories: area, point, mobile and biogenic. Emissions of NOx are produced primarily by motor vehicle engines, power plants, industrial plants, boilers and burning of fossil fuels. VOCs emissions are motor vehicle emissions, gasoline vapors and chemical solvents. Biogenic Volatile Organic Compounds (BVOCs) which almost emitted from forest and marshland like terpenes and isoprene have also

Corresponding Author: Yasmen A. Mustafa, Department of Environmental Engineering, College of Engineering,

University of Baghdad, P.O. Box 47121, J0adria, Baghdad, Iraq Tel: +964 7705094551 
contributed to ozone formation. The impact of biogenic emissions on surface $\mathrm{O}_{3}$ has been examined in many studies. Biogenic volatile organic compounds are a source of hydroperoxy and organic peroxy radicals, which can react with $\mathrm{NO}_{x}$ to stimulate $\mathrm{O}_{3}$ production and react with Peroxy Acetyl Nitrate (PAN) which influence the global distribution of Nitrogen Oxides $\left(\mathrm{NO}_{\mathrm{x}}\right)$ and thus indirectly impact $\mathrm{O}_{3}$ production (Pfister et al., 2008). The high concentration of ozone and other photochemical oxidants are observed over largest cities and metropolitan areas during warm months. Considerable levels of ozone are also found to exist over large rural regions in which ozone gets transported from large urban and industrial areas. Thus, tropospheric ozone is not merely an urban air pollution problem, but also a regional problem (Arya, 1999).

Ozone is well known as strong oxidant. It has a direct effect on human, vegetation and materials. Inhalation of air mass containing $1 \mathrm{ppm}$ by volume ozone causes severe irritation and headache. Ozone irritates eyes, upper respiratory system and lungs. Inhalation of ozone can sometimes cause fatal pulmonary edema which is an abnormal accumulation of fluid in lung tissue. Ozone generates free radicals in tissue. These reactive species can cause lipid peroxidation, oxidation of Sulfhydryl (-SH) groups and other destructive oxidation processes (Manahan, 2004; Palli et al., 2008). Phytotoxicity of ozone is characterizing the yellow and black spots on a green leaf. Wang et al. (2007) show ozone effects on corn and soybeans in both quality and productivity in Linan/China. Quijano et al. (2009), show that phytotoxicity increased with altitude, substantial ozone injury symptoms were found at all altitudes on tobacco plants exposed to the ambient air, although, the damage was more intense in the plants at greatest altitudes. Ground level ozone may cause reduced resistance to fungi, bacteria, viruses and insects. These impacts on sensitive species may result in declines in agricultural crop. Ramo et al. (2006) verify that ozone (40-50 ppb) reduced the total community biomass production and the growth of three species out of seven.

Ozone has a direct effect on materials of reduction for its virtual life. Ozone attacks synthetic rubbers causing deterioration of rubber by cracking. The mechanism appears to be an attack at the double bonds in the hydrocarbon polymer used in the rubber. Some of rubber manufacturers make test to their product by the exposure to high ozone concentration they call it ageing rubber tests. Ozone also attacks the cellulose in textiles, reducing the strength of such items and changing white color of fabric to yellow (Brown et al., 2001).
Because ozone has those harsh effects on both life and material, the United States Environmental Protection Agency (USEPA) considered ozone as a criteria pollutant. USEPA ozone standards have been changed according to the development of research on life requirement. To attain the ozone standard, the 3 year average of the fourth-highest daily maximum $8 \mathrm{~h}$ average ozone concentration measured at each monitor within an area over each year must not exceed 0.075 ppm (NRC, 2008).

In order to estimate how meteorological conditions affect the variation of ozone levels, multiple linear regression analysis was used. Multiple linear regression analysis is one of the most widely used methodologies for modeling the dependence of the response variable (predicted) on several independent variables (predictors), (Khiem et al., 2010). However the multiple linear regression approach can face serious difficulties when the independent variables are correlated to each other (multicollinearity). Multicollinearity is the undesirable situation when one independent variable is a linear function of other independent variables. Multicollinearity indicating that the predictors are highly intercorrelated so that small changes in the data values may lead to large changes in the estimates of the coefficients (Paschilidou et al., 2009). Abdul-Wahab et al. (2005) indicated that multicollinearity, or high correlation between the independent variables in a regression equation can make it difficult to correctly identify the most important contributors to a physical process. The problem can be overcome by omitting the variables that have high multicollinearity (Paschilidou et al., 2009).

The aim of this research is to identify the ground level ozone concentration in Baghdad City at different locations. Five locations are chosen, Al- Dora and AlZa'afarania sites are chosen to show the effect of the thermal power plant (as point source) and AL-Uma Park, Aden Square and AL-Mawal Square is chosen to represent line source. Statistical analysis including multiple linear regression technique was used to model the dependence of ground level ozone concentration on the meteorological parameters for Al-Dora sites.

\section{MATERIALES AND METHODS}

Site description: Baghdad is the capital of Iraq and the center of air, road and rail transport in the country. As the leading manufacturing city of Iraq, the city has numerous oil refineries, power plants, food-processing plants, tanneries and textile mills. The population of Baghdad in 2011 was approximately 7, 216, 040. Iraq's official statistical reports give the total land area as $438,446 \mathrm{~km}^{-2}(169,285 \mathrm{sq} \mathrm{mi})$. It is the largest city in 
Am. J. Environ. Sci., 8 (3): 311-321, 2012

Iraq, the second largest city in the Arab World (after Cairo/Egypt) and the second largest city in Western Asia (after Tehran/Iran). The city is located on a vast plain bisected by the River Tigris. The city is located on flat terrain with no hills or other obstruction around; it is surrounded by flat uncultivated desert. Baghdad has a Subtropical Arid climate, in terms of maximum temperatures, one of the hottest cities in the world. In the summer from June to August, the average maximum temperature is as high as $44^{\circ} \mathrm{C}$ accompanied by blazing sunshine.

Refineries, power plants and vehicle emission that found in the city make air pollution problems and ozone formation possible.

Different sites have been chosen to estimate the ground level ozone in Baghdad City. Different measuring points at Al Dora and Al-Za'afarania Sites were chosen to show the effect of the power plant (as point source) on the formation of ground level ozone, while Aden Square, Al-Mawal Square and Al-Uma Park was chosen to represent line sources. Figure 1 and Table 1 shows the coordinates and the description of these sites.

Data collection: Different equipments have been used to measure both ozone concentration and meteorological parameters (temperature, wind speed, relative humidity and solar radiation). Ozone monitor S-500 from Aeroqual New Zealand Company is used to measure ozone concentration in (ppb), the sensor head for ozone monitor works on Gas Sensitive Semiconductor (GSS) principle. A portable humidity temperature meter model (HT-3015HA) from the Taiwan Lutron Company was used to measure both relative humidity and temperature. A cup anemometer model AM-4221 from Taiwan Lurton Company was used to measure wind speed in $(\mathrm{m} / \mathrm{Sec})$. Sun light intensity meter model (A1010) from MetroQ Company used to measure sunlight intensity in (Lux) and the Geographical Positioning System (GPS) is on Taiwan production with Garmin trade mark model "etrex, Vista, it has been used to define the location in term of longitude and latitude with an accuracy limit of about $5 \mathrm{~m}$. All the equipments were gathered and fixed on composite aluminum bar fixed on a tripod with about $8 \mathrm{~kg}$ weight and $1.6 \mathrm{~m}$ height to simulate respiratory system intakes.

Care must be taken that no high buildings or trees present near the measuring site. Values of the daylight time period were used i.e., from 8: AM to 4: PM Local Standard Time (LST), since this documented as the most important photochemical production period.
Table 1: Measuring sites descriptions

\begin{tabular}{|c|c|c|c|c|c|}
\hline Site & $\begin{array}{l}\text { Name and location of } \\
\text { measuring site }\end{array}$ & Code & Coordinate & & Ozone source \\
\hline$\overline{1}$ & $\begin{array}{l}\text { Aden Square } \\
\text { (North waste of } \\
\text { Baghdad City) }\end{array}$ & $\mathrm{A}$ & N 3321.764 & E 4420.007 & Heavy traffic \\
\hline 2 & $\begin{array}{l}\text { Al Mawal Square } \\
\text { (North waste } \\
\text { of Baghdad City) }\end{array}$ & M & N 3322.194 & E 4424.201 & Heavy traffic \\
\hline 3 & $\begin{array}{l}\text { Al Uma Park } \\
\text { (In the center of } \\
\text { Baghdad City) }\end{array}$ & $\mathrm{U}$ & N 3319.747 & E 4424.628 & Heavy traffic \\
\hline \multirow[t]{5}{*}{4} & Al Za'afarania & $\mathrm{Z} 1$ & N 3317.692 & E 4427.265 & \multirow{4}{*}{$\begin{array}{l}\text { South Baghdad power } \\
\text { Plant and heavy traffic }\end{array}$} \\
\hline & $\begin{array}{l}\text { South east of } \\
\text { Baghdad City, }\end{array}$ & $\mathrm{Z} 2$ & N 3317.127 & E 4427.785 & \\
\hline & (located near South & $\mathrm{Z3}$ & N 3317.294 & E 4426.893 & \\
\hline & $\begin{array}{l}\text { Baghdad power } \\
\text { plant and to the } \\
\text { North East of }\end{array}$ & $\mathrm{Z} 4$ & & & \\
\hline & Al-Dora refinery) & D1 & N 331550.67 & E 442144.7 & \multirow{7}{*}{$\begin{array}{l}\text { Al-Dora power plant } \\
\text { and heavy traffic }\end{array}$} \\
\hline \multirow[t]{6}{*}{5} & Al- Dora & D2 & N 3316.077 & E 4421.87 & \\
\hline & (South of Baghdad & D3 & N 331522.99 & E 442156.13 & \\
\hline & city near the & D4 & N 331530.31 & E 442234.66 & \\
\hline & Al-Dora & D5 & N 3315.348 & E 4422.698 & \\
\hline & power plant) & D6 & N 3315.315 & E 4422.978 & \\
\hline & & D7 & N 3315.281 & E 4422.524 & \\
\hline
\end{tabular}

Hourly observations for 10 days per month were recorded for each area. The measurement focus on spring (March, April and May) and fall (September, October and November), these periods display favorable meteorology to ozone formation in Baghdad City, as indicated by Kanbour et al. (1987) and AL-Quzweny (1990). Other researchers also indicate that these periods display favorable meteorology to ozone formation as in central Makkah, Saudi Arabia (Al-Khalaf, 2006) and in Rabia Area, Kuwait City.

\section{RESULTS AND DISCSSION}

Al-Dora area: Al-Dora area was considered as a case study, the area was expected to be affected by the pollutants which are emitted continuously from AlDora Power Plant and the traffic load. Al-Dora Power Plant located in the south west of Baghdad City and to the west of Al-Dora Refinery and South Baghdad Power Plant (Fig. 1). The wind arose over a period of one full year (2008) was constructed (Fig. 2) using Wrplot V.5.9 program. The wind rose shows that the majority of the prevailing wind were from the west, therefore the measurement points were selected at different locations (D1, D2, D3, D4, D5, D6 and D7) downwind and upwind from Al-Dora Power Plant (Fig. 3 ). Figure $4 \mathrm{a}$ represents the hourly average diurnal variation of ozone concentration and corresponding meteorological parameters at spring and fall for all the locations in Al-Dora area. Figure 4a shows that:

- $\quad$ High ozone peak 87 ppb in 2: PM was observed in fall while a lower peak was observed in spring 50 ppb in 11: AM. In spring, the level of ozone concentration was nearly maintained constant through the daylight time, while in the fall a sharp increase in ozone concentration was observed at 2: PM 


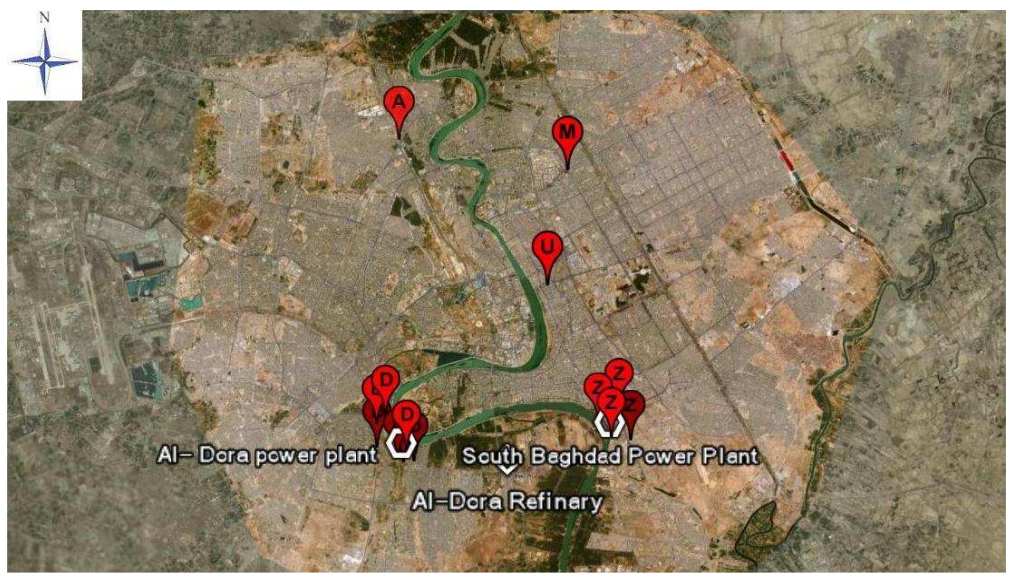

Fig. 1: Aerial photo for Baghdad city shows the measuring sites

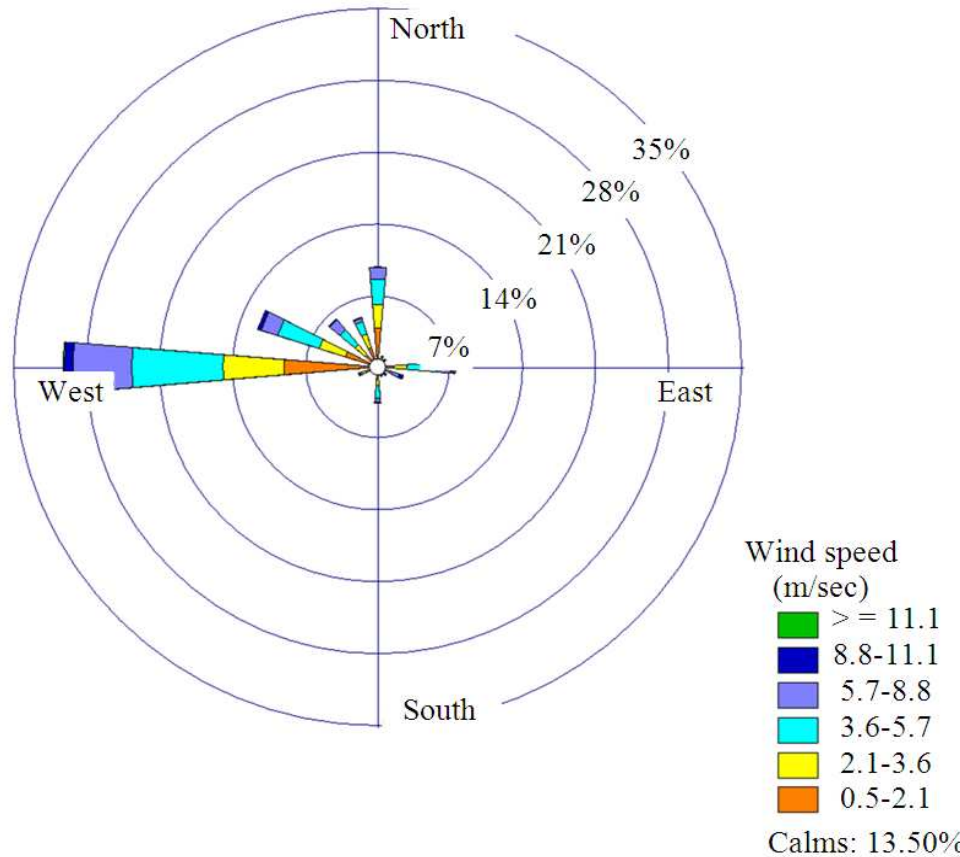

Fig. 2: Wind rose for Baghdad city one full year (2008)

- The back ground concentration of ozone which represents the early recorded value at fall $29 \mathrm{ppb}$ is much higher than the value at a spring which represents $16 \mathrm{ppb}$.

- The solar radiation (about 50 klux), temperature (about $35^{\circ} \mathrm{C}$ ), relative humidity (about $23 \%$ ) and wind speed (about $2 \mathrm{~m} \mathrm{sec}^{-1}$ ) throughout Al-Dora sites, in addition to low mixing height (low inversion layer) that usually observed at fall may be responsible for such higher fall ozone peak . These results coincide with those of Al-Khlaf,
(2006) when he studied the influence of meteorological factors on ozone concentration at central Makkah.

- The highest peak of ozone concentration 236ppb during the research period was observed in this area at point D7 at 2:PM on 16th October 2009, the corresponding temperature was $37^{\circ} \mathrm{C}$, the maximum solar radiation $72 \mathrm{Klux}$, the relative humidity $19 \%$ and the wind speeds $3.7 \mathrm{~m} / \mathrm{s}$ from north direction. 
Al-Za'afarania area: The measurements were located at four points (Z1, Z2, Z3 and Z4) (Fig. 5) downwind and upwind from South Baghdad Power Plant. Figure $4 \mathrm{~b}$ represents an hourly average diurnal variation of ozone concentration and corresponding meteorological parameters at spring and fall for all the locations in $\mathrm{Al}$ Za' afarania Area. From this figure it can be noticed that:

- Two ozone peaks were appearing in all locations. The peaks are nearly at the same height

- Fall represent higher average ozone peaks (90 and $101 \mathrm{ppb})$ as compared with spring (50 and $55 \mathrm{ppb}$ ). Precursors (NOx and VOC) from South Baghdad Power Plant and traffic load with favorable meteorological parameters in addition to low mixing height (low inversion layer) that usually observed at fall may be responsible for such higher ozone peaks

- A shift in peak time can be noticed at fall. In spring, there is a decline in ozone concentration at 12: PM while at fall the decline at 1: PM. No heavy traffic was observed at that time

- The highest concentration of ozone $153 \mathrm{ppb}$ was noticed in this area at the point $\mathrm{Z4}$ at 3: PM on 6th November 2009, the maximum solar radiation was $58 \mathrm{Klux}$, temperature $28^{\circ} \mathrm{C}$, relative humidity $25 \%$ and wind speed $4.3 \mathrm{~m} / \mathrm{Sec}$ from north direction

- Kanbour et al. (1987) during their research period observed that the maximum value of ozone concentration, $285 \mathrm{ppb}$ was recorded at $\mathrm{Al}$ Za'afarania Site in Baghdad City in October 1987.

- Almost all the meteorological data recorded at AlZa' afarania indicate that ozone formation increase with high solar radiation (about 60 klux), high temperature $\left(30^{\circ} \mathrm{C}\right)$ and low relative humidity
$(25 \%)$. Although variable wind speed was observed but in most cases low wind speed will limit the ozone dispersion. A higher wind speed was recorded in Al- Zaafarania $\left(3.4 \mathrm{~m} \mathrm{sec}^{-1}\right.$ as a maximum) as compared with Al-Dora site, also there is a decline in temperature with about $5^{\circ}$ as compared with the temperature prevails in Al-Dora site. These differences in meteorological parameters related to the nature of $\mathrm{Al}-\mathrm{Z}$ 'afarania area which is considered as an open area

Line source area: The measurements were located at three sites, Al-Uma Park, Aden Square and Al-Mawal Square (Fig. 6) which represent areas of high traffic load. Figure $4 \mathrm{c}$ shows the hourly average diurnal variation of ozone concentration and the corresponding meteorological parameters at spring and fall for the above locations. From this figure, the following points can be observed:

- No clear difference in ozone concentration between spring and fall in these areas

- Three peaks were appeared in the fall, $48 \mathrm{ppb}$ at 11: AM, 46ppb at: $1 \mathrm{PM}$ and $49 \mathrm{ppb}$ at $4: \mathrm{PM}$, they represent the rush hours The highest ozone peak in the present research period ( $84 \mathrm{ppb})$ in line source areas was recorded in the Aden Square in 4: PM., on 4th November 2009

- The recorded meteorological parameters at these areas mention that the solar radiation (above 60 Klux) temperature $\left(29^{\circ} \mathrm{C}\right)$ relative humidity (28\%) and wind speed (less than $2 \mathrm{~m} \mathrm{sec}^{-1}$ ) are responsible for the ozone formation, in addition to NOx and VOC that may be emitted from vehicle engines.

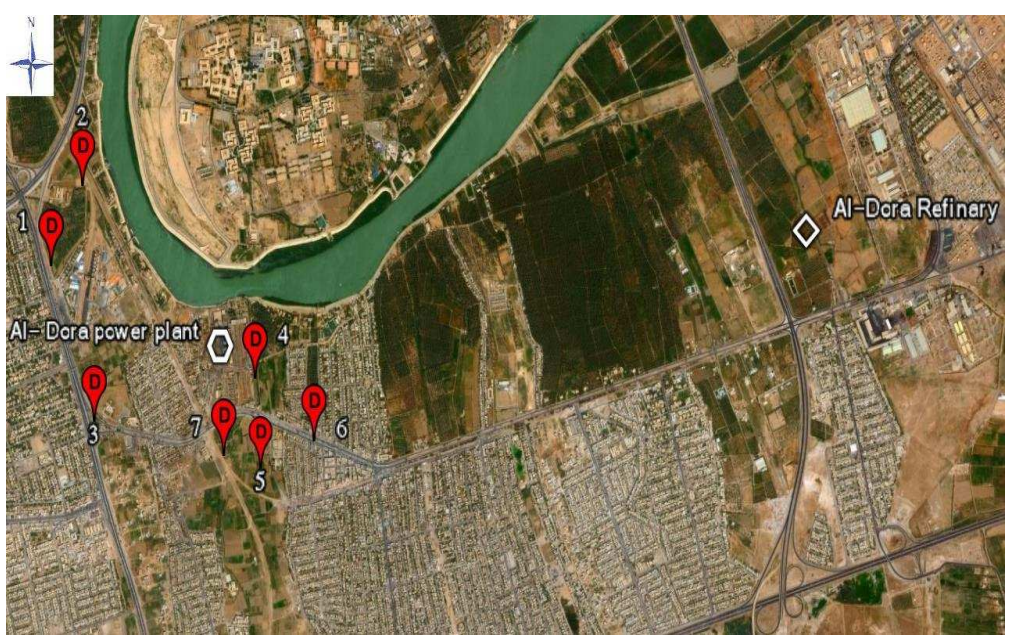

Fig. 3: Aerial photo of Al-Dora area shows the measuring sites around the power plant 

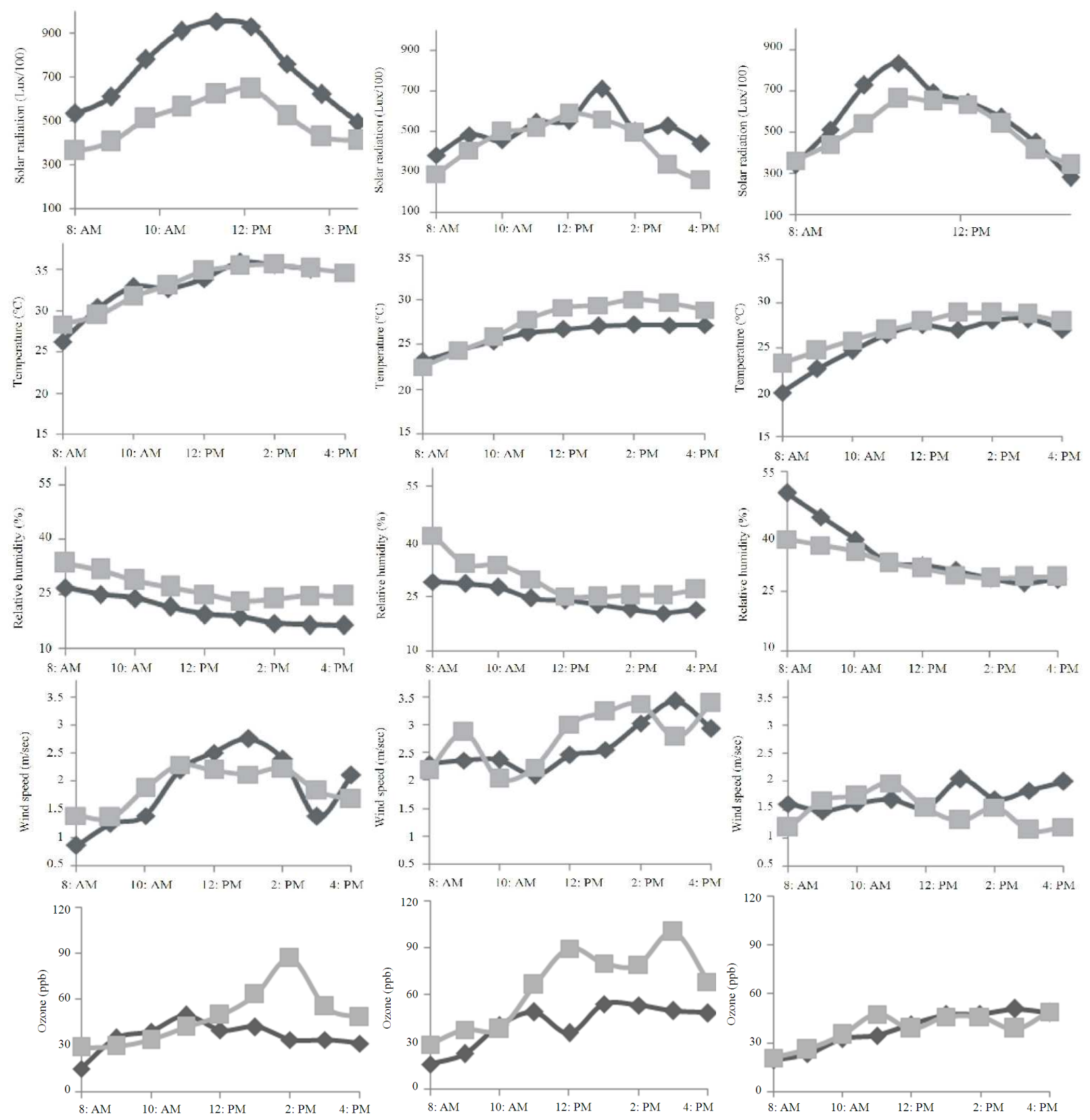

(a)

(b)

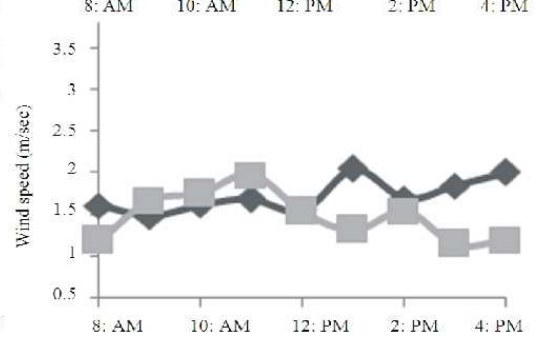

Fig. 4: Diurnal variation of meteorological parameters and ground level zone concentration during spring (black color) and fall (gray color) at (a) Al-Dora site (b) Al-Za'afarania site (c) Line source sites

Comparison between point source, line source and AAQS: It can be noticed from the previous results that line source areas had lower peaks for ground level ozone concentration as compared with areas contained point source at fall (87 ppb for Al-Dora, $101 \mathrm{ppb}$ for Al- Za' afarania and $48 \mathrm{ppb}$ for line source areas). While in spring the peaks were observed to be nearly equal
(50 $\mathrm{ppb}$ in Al-Dora, $51 \mathrm{ppb}$ at Al- Za'afarania and $51 \mathrm{ppb}$ at line source areas).

The comparison between ground level ozone concentration that measured during spring and fall in the areas of present research and the Ambient Air Quality Standards (AAQS) which is $75 \mathrm{ppb}$ as adopted by (NRC, 2008) identify that: 
- $\quad$ No exceeded levels were observed in spring for all sites (Fig. 7a)

- In the fall, the AAQS for ozone was exceeded in Al-Za' afarania area at 12: PM, 1: PM and 3: PM and in Al-Dora at 2: PM (Fig. 7b)

\section{Statistical analysis:}

l-Dora area (fall): In order to estimate how meteorological conditions affect the variation of ozone levels, multiple linear regression analysis was used. Table 2 shows the correlation matrix for the variables measured in Al-Dora area during the fall. The independent variables were chosen to be Solar Radiation (SR) in (Klux), temperature (Temp) in $\left({ }^{\circ} \mathrm{C}\right)$, Relative Humidity (RH), Wind Speed (WS) in (m/sec), Distance (Dist) in $(\mathrm{km})$, background concentration of ozone which is the Early recorded value (EOZ) in (ppb) and the dummy variables for both dates $(\mathrm{y} / \mathrm{m} / \mathrm{d})$ and time of day. These variables were adopted by Galbally et al. (1986).

Linear multiple regression analysis is applied to the above values of the independent variables in order to produce a prediction model for the logarithmic transformation of the ozone concentrations $\ln \left[\mathrm{O}_{3}\right]$. It is noted that the logarithmic transformation of ozone $\ln \left[\mathrm{O}_{3}\right]$ is used instead of $\mathrm{O}_{3}$ because its frequency distribution is closer to the normal and it is well known that the regression analysis works better with normal variables. The analysis of the data was carried out by using the statistical software, Statistical Package for social science, version 17 (SPSS).

The results of the analyses are presented in Table 3, where the estimated regression coefficients, their standard error, the standardized regression coefficients, the coefficients of determination $\mathrm{R}^{2}$, the tolerances and the variance inflation factors VIFs can be seen. Multicollinearity can be observed from Table 3 . The small tolerances show that a high percentage of the variance in a given predictor can be explained by the other predictors. Also it is common practice that VIF greater than 3 is considered problematic. Thus, the high VIF values appeared in the Table are considered unacceptable.

To improve the model, the variables that have high VIF (RH, Temperature and date) can be removed from the model as shown in Table 4. The tolerance and VIF were improved and the multicollinearity was removed. Eq.1 represents the multiple regression results for the standardized values. The results show that $\mathrm{Ln}\left[\mathrm{O}_{3}\right]$ was mostly affected by wind speed, time, solar energy and in less extent by EOZ. Eq. 1 can be acceptable to explain $84 \%$ of the variation in $\mathrm{Ln}_{0}\left[\mathrm{O}_{3}\right]$ by these variables:

$\mathrm{Ln}\left[\mathrm{O}_{3}\right]=0.645 \mathrm{Time}+0.239 \mathrm{SR}+0.677 \mathrm{WS}+0.053 \mathrm{EOZ}$

$\mathrm{R}^{2}=0.84$
Figure 8 illustrates the predicted and the measured values (at 10-16-2009) against the time of the day. The values appeared to fit each other closely.

Table 2: Correlation matrix for Al-Dara area during fall

\begin{tabular}{lrrrrrrrrr}
\hline & Time & Ozone & \multicolumn{1}{l}{ SR } & \multicolumn{1}{c}{ RH } & \multicolumn{1}{c}{ WS } & Temp & Date & \multicolumn{1}{l}{ Dist } & \multicolumn{1}{c}{ EOZ } \\
\hline Time & 1.00 & 0.43 & -0.15 & -0.82 & -0.08 & 0.80 & 0.00 & 0.18 & 0.18 \\
Ozone & 0.43 & 1.00 & 0.22 & -0.36 & 0.69 & 0.33 & 0.38 & -0.31 & -0.31 \\
SR & -0.15 & 0.22 & 1.00 & -0.10 & 0.15 & 0.11 & 0.37 & -0.21 & -0.21 \\
RH & -0.82 & -0.36 & -0.1 & 1.00 & 0.04 & -0.98 & 0.29 & -0.46 & -0.46 \\
WS & -0.08 & 0.69 & 0.15 & 0.04 & 1.00 & -0.15 & 0.48 & -0.50 & -0.50 \\
Temp & 0.80 & 0.33 & 0.11 & -0.98 & -0.15 & 1.00 & -0.36 & 0.55 & 0.55 \\
Date & 0.00 & 0.38 & 0.37 & 0.29 & 0.48 & -0.36 & 1.00 & -0.89 & -0.89 \\
Dist & 0.18 & -0.31 & -0.21 & -0.46 & -0.50 & 0.55 & -0.89 & 1.00 & 1.00 \\
EOZ & 0.18 & -0.31 & -0.21 & -0.46 & -0.50 & 0.55 & -0.89 & 1.00 & 1.00 \\
\hline
\end{tabular}

Table 3: Linear regression analysis of Al-Dora area during fall

\begin{tabular}{|c|c|c|c|c|c|}
\hline \multirow{2}{*}{$\begin{array}{l}\mathrm{R}^{2}=0.92 \\
\mathrm{R}=0.96 \\
\mathrm{P}=2.16 \mathrm{E}-6\end{array}$} & \multicolumn{2}{|c|}{$\begin{array}{l}\text { Unstandardized } \\
\text { efficients }\end{array}$} & \multirow{2}{*}{$\begin{array}{l}\text { Standardized } \\
\text { coefficients } \\
\text { Beta }\end{array}$} & \multicolumn{2}{|c|}{$\begin{array}{l}\text { Collinearity } \\
\text { statistics }\end{array}$} \\
\hline & $\mathrm{B}$ & Std. Error & & Tolerance & VIF \\
\hline$\overline{\text { (Constant) } 5}$ & $\overline{5961 .(}$ & 1307 & & & \\
\hline ime & 7.399 & & & 0064 & 16.35 \\
\hline (1) & 0 & & & & 4.6 \\
\hline RH & 0.280 & 0.060 & 2.0 & 0.0 & 51.550 \\
\hline WS & 0.647 & 0.062 & 0.973 & 0.428 & 2.339 \\
\hline Temp & 0.214 & 0.076 & 1.34 & 0.016 & 62.214 \\
\hline Date & -0.149 & 0.033 & -0.937 & 0.087 & 11.480 \\
\hline $\mathrm{EOZ}$ & -0.029 & 0.011 & -0.494 & 0.111 & 8.974 \\
\hline
\end{tabular}

Table 4:Linear regression analysis after improvement by removing $\mathrm{RH}$, temperature and date

\begin{tabular}{|c|c|c|c|c|c|}
\hline \multirow{2}{*}{$\begin{array}{l}R^{2}=0.84 \\
R=0.92 \\
p=3.85 E-5\end{array}$} & \multicolumn{2}{|c|}{$\begin{array}{l}\text { Unstandardized } \\
\text { coefficients }\end{array}$} & \multirow{2}{*}{$\begin{array}{l}\text { Standardized } \\
\text { coefficients } \\
\text { Beta }\end{array}$} & \multicolumn{2}{|l|}{$\begin{array}{l}\text { Collinearit } \\
\text { statistics }\end{array}$} \\
\hline & $\mathrm{B}$ & Std. Error & & Tolerance & VIF \\
\hline (Constant) & 0.883 & 0.581 & & & \\
\hline Time & 3.336 & 0.581 & 0.645 & 0.958 & 1.044 \\
\hline SR & 0.013 & 0.006 & 0.239 & 0.94 & 1.064 \\
\hline WS & 0.45 & 0.084 & 0.677 & 0.749 & 1.336 \\
\hline EOZ & 0.003 & 0.008 & 0.053 & 0.718 & 1.393 \\
\hline
\end{tabular}

Table 5: Linear regression analysis of Al-Dora area during spring

\begin{tabular}{|c|c|c|c|c|c|}
\hline \multirow{2}{*}{$\begin{array}{l}R^{2}=0.79 \\
R=0.89 \\
p=0.005\end{array}$} & \multicolumn{2}{|c|}{$\begin{array}{l}\text { Unstandardized } \\
\text { coefficients }\end{array}$} & \multirow{2}{*}{$\begin{array}{l}\text { Standardized } \\
\text { coefficients } \\
\text { Beta }\end{array}$} & \multicolumn{2}{|c|}{$\begin{array}{l}\text { Collinearity } \\
\text { statistics }\end{array}$} \\
\hline & B & Std. Error & & Tolerance & VIF \\
\hline (Constant) & 3.965 & 2.487 & & & \\
\hline Time & -0.488 & 1.959 & -0.170 & 0.045 & 22.472 \\
\hline SR & 0.013 & 0.005 & 0.869 & 0.233 & 4.298 \\
\hline $\mathrm{RH}$ & -0.049 & 0.050 & -0.639 & 0.048 & 20.720 \\
\hline WS & -0.082 & 0.088 & -0.241 & 0.310 & 3.221 \\
\hline Temp & -0.009 & 0.039 & -0.092 & 0.134 & 7.458 \\
\hline EOZ & 0.023 & 0.012 & 0.692 & 0.151 & 6.644 \\
\hline
\end{tabular}

Table 6: Linear regression analysis after improvement by removing

\begin{tabular}{|c|c|c|c|c|c|}
\hline \multirow{2}{*}{$\begin{array}{l}\mathrm{R}^{2}=0.77 \\
\mathrm{R}=0.87 \\
\mathrm{p}=0.001\end{array}$} & \multicolumn{2}{|c|}{$\begin{array}{l}\text { Unstandardized } \\
\text { coefficients }\end{array}$} & \multirow{2}{*}{$\begin{array}{l}\text { Standardized } \\
\text { coefficients } \\
- \text { Beta }\end{array}$} & \multicolumn{2}{|c|}{$\begin{array}{l}\text { Collinearity } \\
\text { statistics }\end{array}$} \\
\hline & B & Std. Error & & Tolerance & VIF \\
\hline (Constant) & 1.63 & 0.415 & & & \\
\hline Time & 1. & 0.4 & 0 & 0.822 & 1.216 \\
\hline WS & $-.080-$ & 0.082 & -0.236 & 0.326 & 3.005 \\
\hline EOZ & 0.021 & 0.007 & 0.613 & 0.424 & 2.359 \\
\hline SR & 0.016 & 0.003 & 1.030 & 0.376 & 2.661 \\
\hline
\end{tabular}


Am. J. Environ. Sci., 8 (3): 311-321, 2012

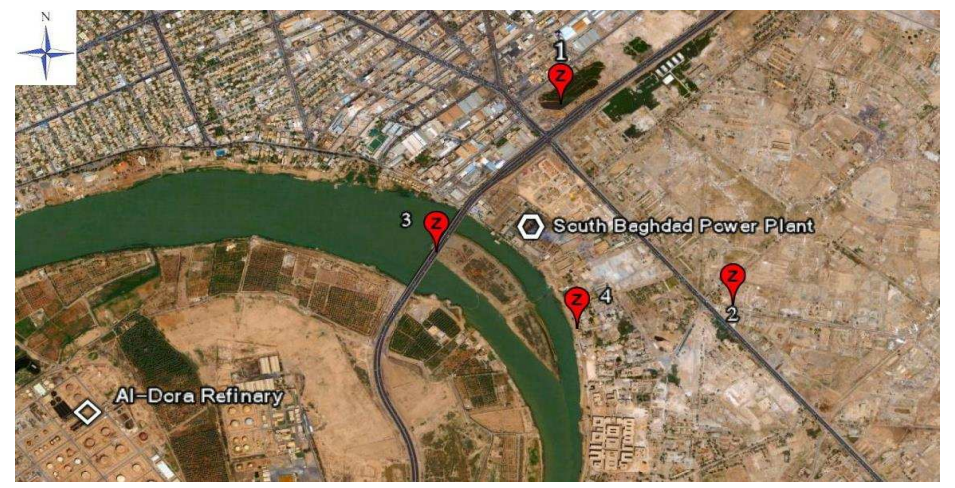

Fig. 5: Aerial photo for Al-Za'afarania area shows the measuring sits around the power plant
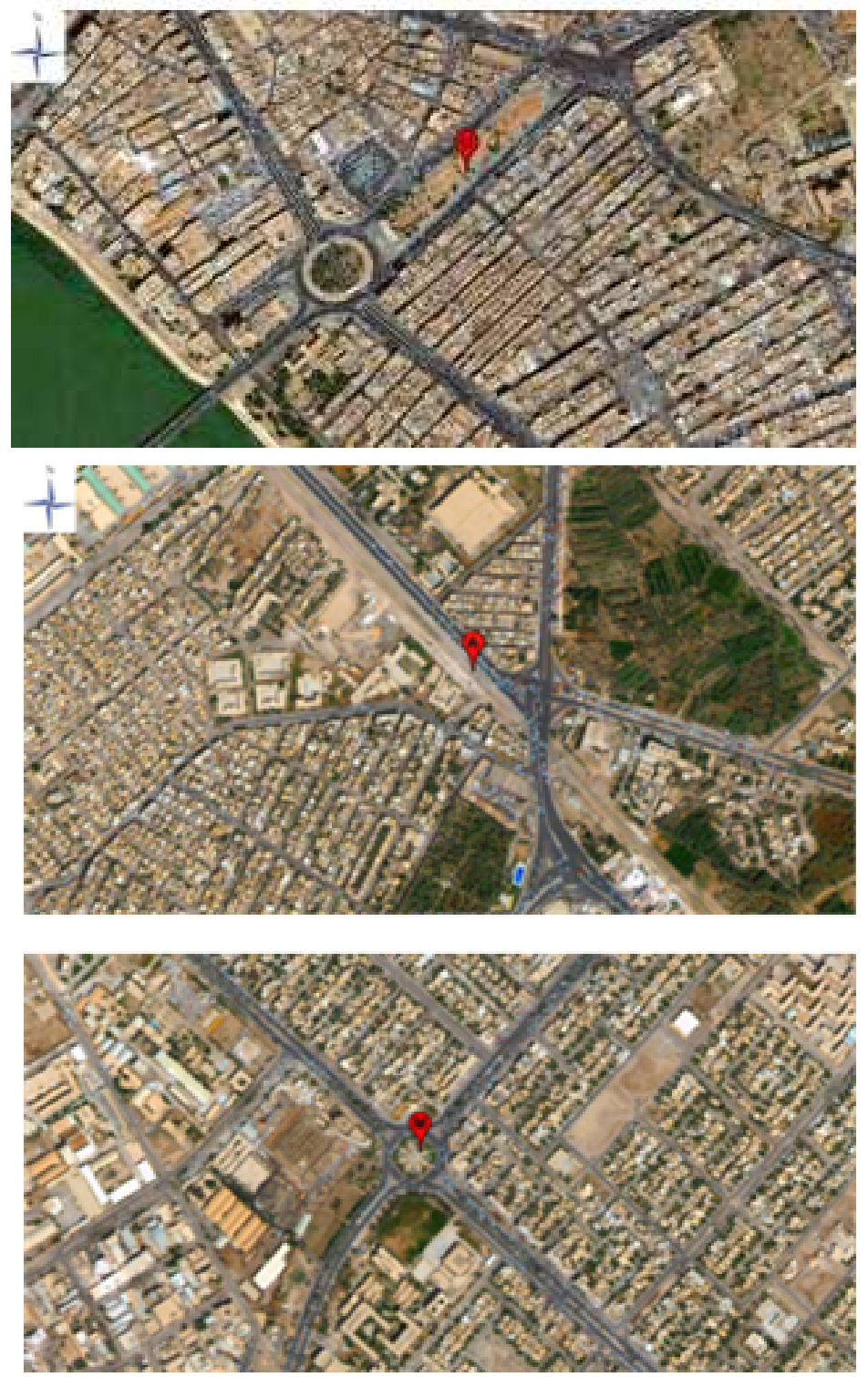

Fig. 6: Aerial photos for the line source area (U) Uma park (A) Aden and (M) Al-Mawal Square 

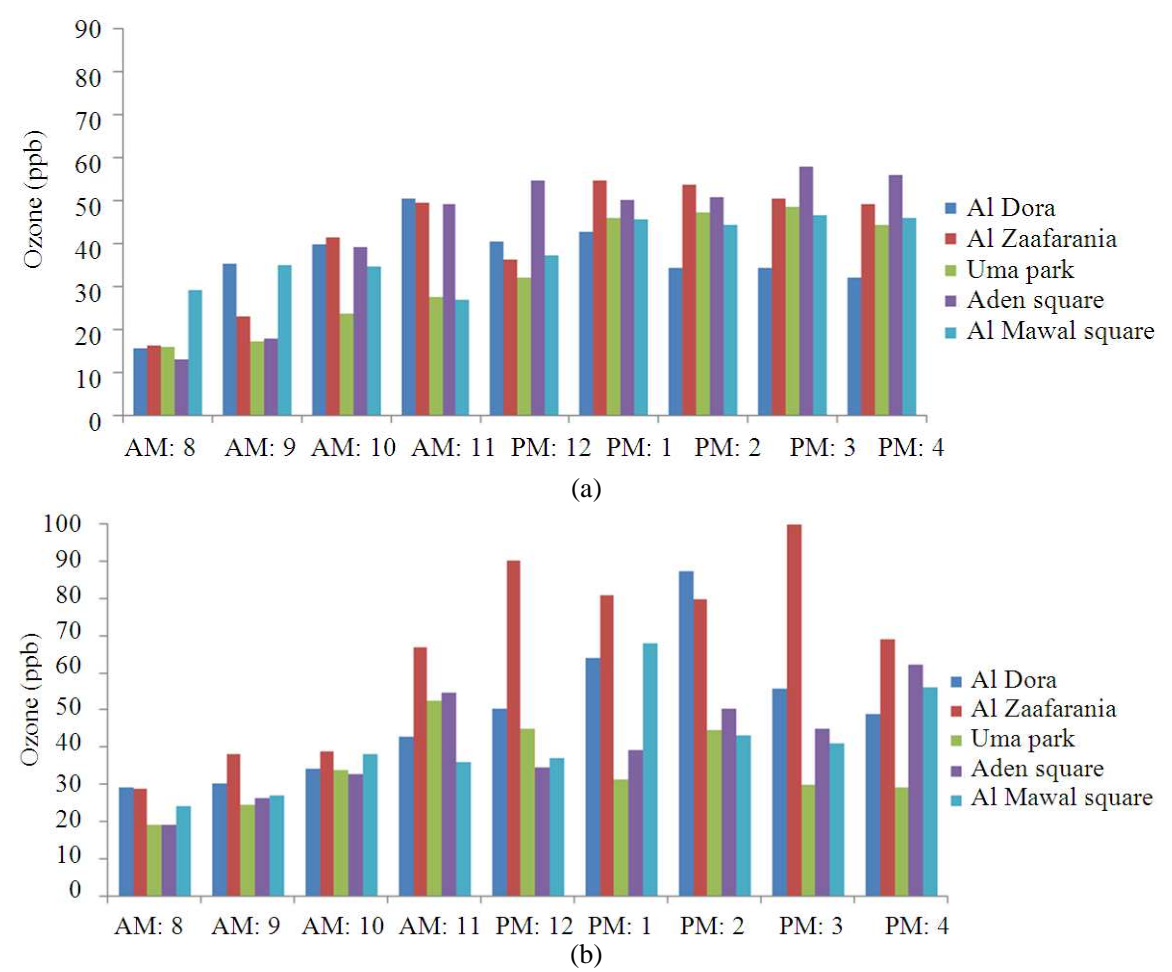

Fig. 7: Compression between measured values and AAQS (a) Spring (b) fall

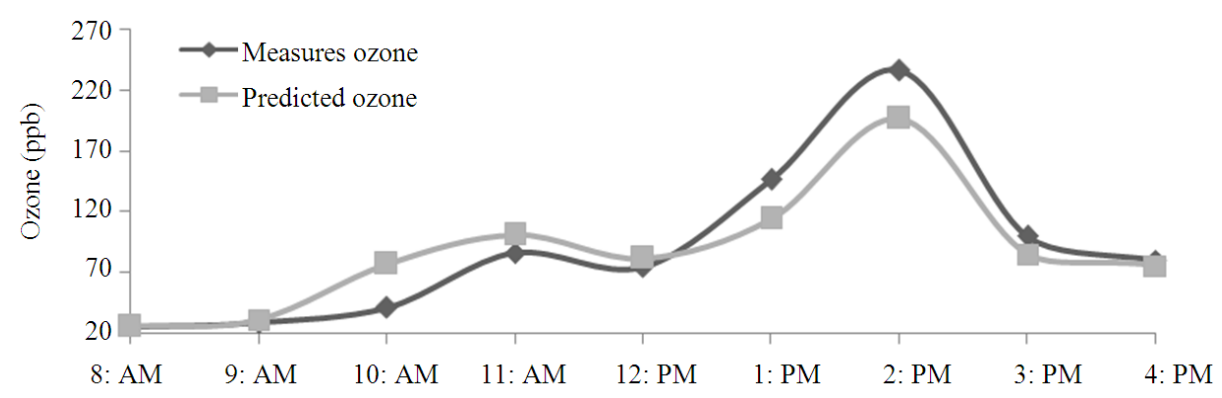

Fig. 8: Predicted and measured values of ground level ozone concentration according to the time of day (fall 16-10-2009)

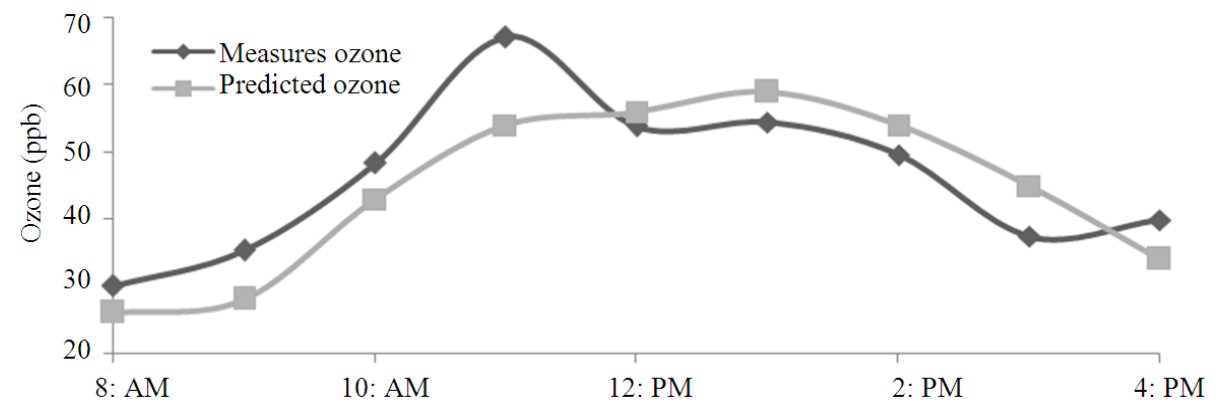

Fig. 9: Predicted and measured values of ground level ozone concentration according to the time of day (spring 4-3-2009) 
Al-Dora Area (spring): Table 5 and 6 show the linear regression analysis for spring at Al-Dora Area before and after the improvement. Eq.2 represents the results for the standardized values. $\mathrm{Ln}\left[\mathrm{O}_{3}\right]$ was affected by SR, EOZ and Time positively and affected by WS negatively. Equation 2 can be acceptable to explain $77 \%$ of the variation in $\mathrm{Ln}\left[\mathrm{O}_{3}\right]$ :

Ln $\left[\mathrm{O}_{3}\right]=0.406$ Time-0. 236WS+0.613 EOZ+1. 03SR $\mathrm{R}^{2}=0.77$

Figure 9 shows the predicted and measured values of ground level ozone concentration according to the time of day in spring (3-4-2009). The deviation between the predicted and the measured values is due to other predictor (independent variables) as: wind direction, mixing height pressure and the ozone precursors as $\mathrm{NO}_{2}, \mathrm{NO}, \mathrm{CO}, \mathrm{SO}_{2}$ and VOCs, which are not considered in this study.

\section{CONCLUSION}

The following conclusions can be considered for the present research:

- The highest ground level ozone concentration was found during fall in all sites, the peaks of ozone concentration appeared clearly in the fall as compared with spring

- The highest average peak of ground level ozone concentration was found during fall in $\mathrm{Al}-\mathrm{Za}$ 'afarania area, $101 \mathrm{ppb}$ in 3: PM. This probably due to the precursors (NOx and VOC) that emitted from South Baghdad Power Plant, the traffic load, the favorable meteorological parameters, the low mixing height (low inversion layer) that usually observed in the fall, in addition to the effect of al-Dora Refinery

- It was found that no clear variation in ozone concentration between spring and fall in line source areas

- The area contained point source represent higher ozone peaks as compared with areas contained line source only in the fall, while in spring the peaks were observed to be approximately equal

- Ozone formation was enhanced by high solar radiation (about 60 Klux), high temperature $\left(30^{\circ} \mathrm{C}\right)$, low relative humidity $(25 \%)$ and low wind speed (less than $2 \mathrm{~m} \mathrm{sec}^{-1}$ )

- AAQS for ozone was exceeded in Al- Za'afarania areas at 12: PM, 1: PM and 3: PM and in Al-Dora at 2: PM in the fall

- The best prediction equation $\left(\mathrm{R}^{2}=0.84\right)$ that shows the dependence of ozone concentration on the predictors in Al-Dora area was obtained in fall by using multiple linear regression analysis

\section{REFERENCES}

Abdul-Wahab, S.A., C.S. Bakheit and S.M. Al-Alawi, 2005. Principal component and multiple regression analysis in modelling of ground-level ozone and factors affecting its concentrations. Environ. Model. Software, 20: 1263-1271. DOI: 10.1016/j. envsoft. 2004.09.001

Al-Alawi, S.M, S.A. Abdul-Wahab and C.S. Bakheit, 2008. Combining principal component regression and artificial neural networks for more accurate predictions of ground level ozone. Environ. Model. Software, 23: 396-403. DOI: 10.1016/j. envsoft. 2006.08.007

Al-Khalaf, K.A., 2006. Influence of meteorological and related factors on surface ozone pattern at Makkah station. J. Environ. Sci. Instit. Environ. Stud. Res., 1-19.

Al-Quzweny, B.B., 1990. Measurement of air pollutant in Baghdad city: Nitrogen oxide and Ozone. M. Sc Thesis, University of Baghdad.

Arya, S.P., 1999. Air Pollution Meteorology and Dispersion. 1st Edn., Oxford University Press, USA, ISBN-10: 0195073983, pp: 310.

Brown, R.P., T. Butler, S.W. Hawley, 2001. Ageing of Rubber: Accelerated Weathering and Ozone Test Results. 1st Edn., iSmithers Rapra Publishing, Shrewsbury, ISBN-10: 1859572642, pp: 200.

Eijkeren, V.J.C., J.I. Freijer and L. Van Bree, 2002. A model for the effect on health of repeated exposure to ozone. Environ. Model. Software, 17: 553-562. DOI: 10.1016/S1364-8152 (02)00021-X

Galbally, I.E., A.J. Miller, R.D. Hoy, S. Ahmet and R.C. Joynt et al., 1986. Surface ozone at rural sites in the Latrobe valley and cape grim, Australia. Atmos. Environ., 20: 2403-2422.

Jose, R.S., A. Stohi, K. Karatzas, T. Bohler and J. Perez, 2005. A modelling study of an extraordinary night time ozone episode over Madrid domain. Environ. Model. Software, 20: 587-593. DOI: 10.1016/j. envsoft. 2004.03.009

Kanbour, F.I., S.Y. Faiq, F.A. Al-Taie, A.M.N. Kitto and N. Bader, 1987. Variation of ozone concentrations in the ambient air of Baghdad. Atmos. Environ., 21: 2673-2679.

Khiem, M., R. Ooka, H. Huang, H. Hayami and H. Yoshikado et al., 2010. Analysis of the relationship between changes in meteorological conditions and the variety in summer ozone levels over the central Kanto area. Adv. Meteorol., 2010: 1-13. DOI: $10.1155 / 2010 / 349248$ 
Langyel, A., K. Hebergerc, L. Paksya, O. Banhidia and R. Rajko, 2004. Prediction of ozone concentration in ambient air using multivariate methods. Chemosphere, 57: 889-896. DOI: 10.1016/j. Chemosphere. 2004.07.043

Manahan, S.E., 2005. Environmental Chemistry. 8th Edn., CRC Press, Boca Raton, Fla., ISBN-10: 1566706335, pp: 783.

NRC, 2008. Estimating Mortality Risk Reduction and Economic Benefits from Controlling Ozone Air Pollution. 1st Edn., National Academies Press, Washington, D.C., ISBN-10: 0309119944, pp: 212.

Palli, D., F. Sera, L. Giovannelli, G. Masala and D. Grechi et al., 2008. Environmental ozone exposure and oxidative DNA damage in adult residents of Florence, Italy. Environ. Poll., 157: 1521-1525. DOI: $10.1016 /$ j.envpol.2008.09.011

Paschilidou, A., P. Kassomenos and A. Bartzokas, 2009. A comparative study of various statistical techniques predicting ozone concentrations: implications for environmental management. Environ. Monit. Asses., 148: 277-289. DOI: 10.1007/s10661-008-0158-0
Pfister, G., K. Emmons, P. Hees, J. Lamarque and J. Orlando et al., 2008. Contribution of isoprene to chemical budgets: A model tracer study with the NCAR CTM MOZART-4. J. Geophys. Res. Atmos., 113: 21-33. DOI: 10.1029/2007JD008948

Quijano, M., J. Peủelas and A. Ribas, 2009. Increasing internal and attitudinal ozone mixing ratios in the Catalan Pyrenees. Atmos. Environ., 43: 6049-6057. DOI: 10.1016/j.atmosenv.2009.08.035

Ramo, K., T. Kanvera, S. Nikula, K. Ojanpera and S. Mannine, 2006. Influences of elevated ozone and carbon dioxide in growth responses of lowland hay meadow mesocosms. Environ Poll., 144: 101-111. DOI: 10.1016/j.envpol.2006.01.009

Wang, X., W. Manning, Z. Feng and Y. Zhu, 2007. Ground level zone in china: Distribution and effects on crop yields. Environ. Poll., 147: 394400. DOI: 10.1016/j. envpol. 2006.05.006 